\section{栗駒火山雪溪地域のグライ土搳}

村 山

磐

グライ土壌は停滞水の存在する地域にみられ るが，残雪地域に生成されているという報告は ない。栗駒火山以第三系堆積岩上に第四紀沈 って形成されたものと推定され，頂上付近は数 ケ所の爆裂火口壁があり, 両輝石安山岩質熔岩 から構成されている。山麓は安山岩の巨碅・中 磁・小碩からなる泥流堆積物で形成され，マ トリッス性褐色火山灰である。記録（気象庁 1959）によると小規模の火山活動は 2 回あった が，この時は火山灰を堆積させるような活動で はなく，また黒色火山灰（村山 1965）は分布 せず，有史以前に降灰したと考它られる褐色火 山灰（おもに $10 \mathrm{YR} 4 / 6$ ）が分布している。 $\mathrm{pH}$ 5.5〜 5.7 $\left(\mathrm{H}_{2} \mathrm{O}\right), \mathrm{pH} 4.4 \sim 5.1(\mathrm{KCl})$ を示 す。鏡検に上ると火山灰粒径怯，葴王火山の褐 色火山灰上り小さく, 風化溶脱が進渉している が, 斜長石などの微晶が認められる。腐植やグ ライ化によって $\mathrm{pH}$ 值・土色が変化している。

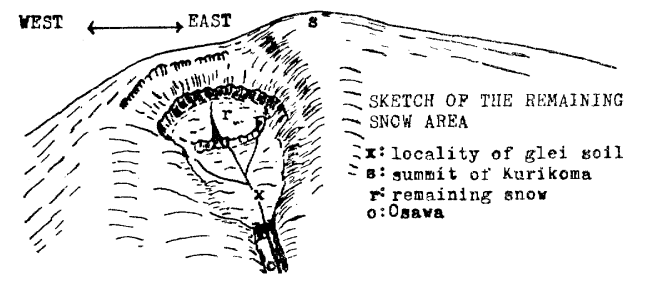

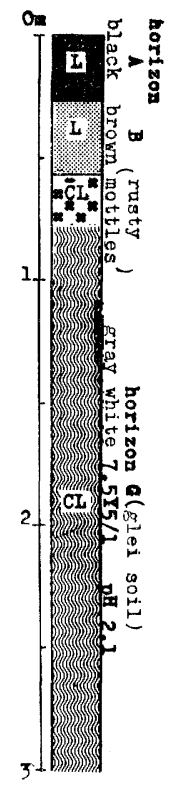

グライ土堙は雪渓地域以外に山 麓湿地带にも観察される。

雪溪位置は，頂上の南西斜面 の標高約 1,200m 地点にある 侵蝕が相当進んだ爆裂火口壁下 の山地にあり，雪溪付近の褐色 火山灰搹雪水によって湿潤と なり，下層はグライ化作用を受 けている。土䁃断面では一見， 褐色低地士に類似し，A層は腐 植に富さ黒色堹土であり，B層 は褐色壤土となっており，A． $\mathrm{B}$ 層とも弱酸性を示すが， G 層 は強酸性を呈し，上部には斑鉄 が存在する。これは融雪による 停滞水が火山灰を急速に溶脱さ せた結果と思われ，また $\mathrm{A} \cdot \mathrm{B}$ 層が強酸性を呈しない一因は, 斜長石の含有にあるとも考它れる。

以上のようにこの稿では, 褐色火山灰が雪渓 によってグライ化作用を受け，粘土化され，強 酸性を呈しているということを述べるに止め る。

(1965.12. 11 受理)

気像庁 (1959) : 日本噴火誌 栗駒山〈ブリント版)

村山 磐 (1965)：蔵王火山東麓火山灰の堆樍時期 と土铱学的特性 東北地理 1750

\title{
Glei Soil in the Remaining Snow Area of the Kurikoma Volcanoes Iwao MURAYAMA
}

All the volcanic ashes have been formed by certain developmental processes, which are continuous. Brown volcanic ash is accumulated at the foot of the Kurikoma volcanoes, but no black volcanic ash with colored minerals was found there. In the west areas at the feet of the volcanoes, the brown volcanic ash is changed into glei soil which shows a gray white color due to the underground water. Some of glei solis are formed by melting water of the remaining snow in the southern part of the summit of the volcanoes. Rusy mottles are shown in the upper part of glei horizon. The relation between gleization and the remaining snow area is an interesting phenomenon. 